\title{
GAMBARAN FAKTOR PREDISPOSING, ENABLING DAN REINFORCING KB VASEKTOMI
}

\author{
DESCRIPTION OF FACTORS PREDISPOSING, ENABLING AND REINFORCING \\ OF VASECTOMY
}

\section{Shelly Rosalina Febrianti}

Departemen Promosi Kesehatan dan Ilmu Perilaku, Fakultas Kesehatan Masyarakat, Universitas Airlangga, Surabaya

E-mail: shellyirfani@gmail.com

\begin{abstract}
Background: Family Planning Program is a program that can be adobted by men and women but for male participation is still low that is $0.3 \%$. In Surabaya, the target of vasectomy from 31 sub-districts is only 8 districts (26\%) who have reached the target of active participants of $K B$ Vasectomy. Kenjeran sub-district is one of the sub-districts that has reached the target of vasectomy and has family vasectomy group which has active participants. Purpose: The aims of this study was to identify the factors oh male participation in vasectomy contraception in the Kenjeran District of Surabaya. Methods: The design of this research is a qualitative research with phenomenology approach. The research informants were 9 people, 6 were key informants ie men who followed $K B$ vasectomy and 3 additional informants, the wife of the key informant. Results: The results showed the number of informants as many as 9 people with age range elderly. The predisposing factor showed good knowledge, attitude and belief about vasectomy method. The reinforcing factors showed most informants have the support of the wives and the male family planning group who has a role as a motivator and deseminator. The affordability cost and good service are enabling factors men to participate on vasectomy method. Conclusion: The conclusion of this research is informant have desire to participate to $K B$ vasectomy, proved by the finding of factors that support man to do $K B$ vasectomy.
\end{abstract}

Keywords: Family Planning, Vasectomy, Participation

\begin{abstract}
ABSTRAK
Latar Belakang: Program KB merupakan program yang dapat dilaksanakan oleh pria dan wanita namun untuk partisipasi pria masih rendah yaitu 0,3\%. Di Kota Surabaya pencapaian target vasektomi dari 31 kecamatan hanya 8 kecamatan (26\%) yang telah mencapai target peserta aktif KB Vasektomi. Kecamatan kenjeran merupakan salah satu kecamatan yang telah mencapai target vasektomi serta memiliki paguyuban KB vasektomi yang memiliki peserta aktif. Tujuan: Tujuan dari penelitian ini adalah untuk mengidentifikasi faktor keikutsertaan pria dalam mengikuti KB vasektomi di Kecamatan Kenjeran Kota Surabaya. Metode: Desain penelitian ini adalah kualitatif dengan pendekatan fenomenologi. Informan penelitian berjumlah 9 orang yaitu 6 orang pria yang mengikuti KB vasektomi dan 3 orang istri dari peserta KB vasektomi. Hasil: Hasil penelitian menunjukkan bahwa yang menjadi faktor predisposisi adalah pengetahuan, sikap dan keyakinan yang baik terhadap metode KB vasektomi. Faktor penguat menunjukkan bahwa sebagian besar informan mendapat dukungan istri dan paguyuban yang memiliki peran sebagai motivator dan deseminator. Biaya terjangkau serta pelayanan yang baik menjadi faktor pemungkin pria mengikuti metode KB vasektomi. Kesimpulan: Informan memiliki keinginan untuk ikut berpartisipasi terhadap KB vasektomi, terbukti dengan ditemukannya faktor-faktor yang mendukung pria untuk melakukan KB vasektomi.
\end{abstract}

Kata Kunci: Keluarga Berencana, Vasektomi, Partisipasi 
114 J urnal Promkes: The Indonesian J ournal of Health Promotion and Health Education Vol. 7 No. 1 (2019) 113-123. doi: 10.20473/jpk.V7.I1.2019.113-123

\section{PENDAHULUAN}

Di Indonesia, masalah kependudukan masih menjadi masalah yang harus mendapat perhatian khusus. Peran pemerintah tidak akan cukup untuk mengatasi masalah pengendalian penduduk, peran serta dari masyarakat sangat diperlukan untuk menekan laju peningkatan penduduk. Laju pertumbuhan penduduk Indonesia meningkat cukup pesat dari tahun ke tahun. Pada tahun 1990 berjumlah 179.378.946 jiwa yang kemudian meningkat pada tahun 2010 menjadi 237.641 .324 jiwa. Selama kurun waktu 20 tahun terjadi lonjakan sebesar 197,4 juta jiwa (BKKBN, 2016).

Data angka kelahiran menurut jenis kelamin (sex ratio) di Provinsi Jawa Timur khususnya Surabaya juga mengalami peningkatan. Tahun 2007, angka kelahiran pada laki-laki sebesar 1.421.573 jiwa dan pada perempuan sebesar 2.829.552 jiwa. Pada tahun 2013, , sex ratio mengalami peningkatan yaitu angka kelahiran laki-laki sebesar 1.602.875 jiwa dan perempuan sebesar 3.200.454 jiwa. Peningkatan penduduk yang cukup pesat dapat memberi dampak tidak langsung bagi kesehatan masyarakat (DINKOMINFO Surabaya, 2013).

Pada tahun 1970 program Keluarga Bencana (KB) dijadikan sebagai upaya untuk mengendalikan jumlah penduduk. Tujuan dari pelayanan KB adalah untuk memperoleh kualitas kesehatan reproduksi yang baik, menurunkan angka kematian Ibu dan Bayi, dan menanggulangi masalah reproduksi sehingga terbentuk keluarga kecil yang berkualitas (BKKBN, 2016). Program Keluarga Berencana berhubungan erat dengan penggunaan alat kontrasepsi. Alat kontrasepsi digunakan pasangan suami istri untuk menunda atau mengatur kehamilan. Penggunaan alat kontrasepsi bukan merupakan tanggung jawab wanita saja, namun juga merupakan tanggung jawab pihak laki-laki. Pasangan suami istri harus saling mendukung pemilihan penggunaan metode atau alat kontrasepsi yang akan digunakan (Dalem, 2012).

Cakupan partisipasi wanita dalam penggunaan metode kontrasepsi telah banyak menunjukkan data tercapainya target. Data perkiraan peminatan permintaan masyarakat terhadap metode kontrasepsi pada bulan Januari 2016 menunjukkan bahwa kontrasepsi KB suntik 373.190 orang $(47,4 \%)$ paling banyak dipilih oleh Pasangan Usia Subur (PUS) di Jawa Timur (BKKBN, 2016).

Penggunaan alat kontrasepsi pada pria meliputi kondom (3\%), senggama terputus (3\%), vasektomi hanya $0,3 \%$. Data tersebut mempertegas bahwa keikutsertaan pria mengikuti $K B$ masih sangat rendah terutama dalam menggunakan metode vasektomi. Metode Operasi Pria (MOP) atau disebut dengan vasektomi adalah prosedur klinik yang dilakukan untuk menghentikan kapasitas reproduksi pria dengan cara mengoklusi vas deferensia sehingga mencegah sperma bertemu dengan sel ovum dan tidak terjadi proses fertilisasi. Vasektomi dapat dilakukan setiap saat jika syarat menjadi akseptor telah dipenuhi. Keuntungan dari vasektomi adalah aman dijadikan sebagai metode kontrasepsi, tidak terdapat efek samping jangka panjang, efektivitas tinggi yaitu $99,6 \%-99,8 \%$. Keterbatasan dari vasektomi adalah tidak dapat bekerja secara efektif karena diperlukan pemakaian kontrasepsi tambahan selama 3 bulan setelah prosedur dilakukan atau kurang lebih 20 kali ejakulasi. Selain itu keterbatasan yang lain adalah dilakukan pembedahan atau jika menginginkan teknik tanpa piasau efeknya akan terasa lebih nyeri dan kemungkinan ada komplikasi ringan (BKKBN, 2012).

Tabel 1. Pencapaian Peserta Baru KB Vasektomi di Provinsi Jawa Timur

\begin{tabular}{lcc}
\hline \multicolumn{1}{c}{ Bulan } & $\begin{array}{c}\text { Perkiraan } \\
\text { Permintaan } \\
\text { Masyarakat } \\
\text { (PPM) }\end{array}$ & Pencapaian \\
\hline November & 1.934 & 1.055 \\
2015 & 1.934 & 1.093 \\
$\begin{array}{l}\text { Desember } \\
2015\end{array}$ & & 23 \\
Januari 2016 & 1.140 & 23 \\
\hline
\end{tabular}

Sumber: Data Pelayanan Kontrasepsi BKKBN

Saat ini, partisipasi pria dalam menggunakan alat atau metode kontrasepsi masih rendah. Pencapaian akseptor vasektomi mengalami penurunan dari waktu ke waktu. Hasil laporan BKKBN Jawa Timur menjelaskan mengenai Perkiraan Permintaan (PPM) terkait KB metode 
vasektomi dengan pencapaian target yang dicapai dijelaskan dengan Tabel 1.

Pengguna metode vasektomi berdasarkan Tabel 1 mengalami penurunan. Pada bulan Desember 2015 tercatat pencapaian peserta baru KB vasektomi yaitu 1.093 orang, namun pada bulan Januari 2016 pencapaian yang baru terhitung adalah 23 orang (BKKBN, 2016).

Tabel 2. Pelayanan Peserta Baru KB Vasektomi Kota Surabaya

\begin{tabular}{lc}
\hline \multicolumn{1}{c}{ Bulan } & $\begin{array}{c}\text { Pencapaian } \\
\text { Pelayanan }\end{array}$ \\
\hline November 2015 & 20 \\
Desember 2015 & 21 \\
Januari 2016 & 4 \\
Februari & 4 \\
\hline
\end{tabular}

Sumber: Data Pelayanan Kontrasepsi BKKBN

Penggunaan metode vasektomi ditinjau dari pencapaian pelayanan KB baru vasektomi di Surabaya berdasarkan Tabel 2 belum maksimal. Pada bulan November 2015 tercatat pencapaian peserta baru KB vasektomi tidap bulannya 20 orang, sedangkan pada bulan Februari 2016 pencapaiannya hanya 4 orang (BKKBN, 2016). Di Kota Surabaya pencapaian target vasektomi dari 31 Kecamatan hanya 8 Kecamatan (26\%) yang telah mencapai target pesera aktif KB Vasektomi yaitu di Kecamatan Wonokromo, Tegalsari, Gubeng, Simokerto, Tandes, Lakarsantri, Kenjeran, Benowo, dan Semampir. Bahkan dari 8 Kecamatan tersebut, pada Kecamatan Kenjeran dan Semampir telah memiliki paguyuban. Anggota paguyuban tersebut adalah orang yang telah memakai KB Vasektomi atau disebut dengan peserta aktif KB Vasektomi.

Peserta aktif KB vasektomi terbanyak berdasarkan data Bapemas dan KB terbaru pada bulan Februari 2016 di Kota Surabaya terletak di Kecamatan Kenjeran, yaitu mencapai 216 orang peserta. Kecamatan Kenjeran memiliki 4 Kelurahan, yaitu Kelurahan Bulak Banteng, Kelurahan Tambakwedi, Kelurahan Tanahkali Kedinding dan Kelurahan Sidotopo Wetan. Luas wilayah Kecamatan Kenjeran terbilang cukup luas dan berada di dekat pesisir pantai. Penduduknya tidak hanya berasal dari suku Jawa, tetapi ada juga yang berasal dari suku Madura. Keberagaman tersebut membuat daerah ini memiliki berbagai karakteristik penduduk.

Pemakaian KB dengan metode vasektomi menimbulkanu banyak pertimbangan para pria untuk memakai ataupun menentukan alat kontrasepsi yang akan digunakannya. Terutama pada daerah yang memiliki keberagaman karakteristik penduduk, dalam pemilihan kontrasepsi akan banyak faktor yang mempengaruhi. Hasil penelitian Wiwik (2014) menyebutkan bahwa akseptor KB MOP lebih banyak pada usia 30-50 tahun.

Umur merupakan suatu indikator kedewasaan untuk mengambil suatu keputusan yang bisa didasari berdasarkan pengalaman yang dimiliki. Variabel umur memiliki peranan cukup penting karena bisa memberikan gambaran faktor penyebab suatu kejadian penyakit, serta menjadi faktor yang dapat diperhitungkan pada saat melakukan pengamatan kejadian penyakit (Noor, 2008).

Tingkat pendidikan dan pengetahuan juga sangat berpengaruh sebagai pertimbangan seseorang dalam pengambilan keputusan. Faktor struktur sosial dalam hal ini misalnya adalah pekerjaan dan penghasilan seseorang yang berpengaruh juga dengan keikutsertaan dalam melakukan perilaku khususnya dalam bidang kesehatan. Hal ini tergambar dalam terbentuknya sebuah paguyuban didaerah Kecamatan Kenjeran. Paguyuban tersebut merupakan komunitas atau kumpulan pria dengan berbagai karakteristik yang memutuskan untuk melakukan vasektomi.

Banyak faktor yang dapat mempengaruhi perubahan perilaku manusia. Konsep umum yang akan digunakan untuk penelitian ini adalah berdasarkan teori Lawrence Green yang menyebutkan bahwa perilaku manusia terbentuk karena faktor predisposisi, faktor pendukung dan faktor penguat. Berdasarkan latar belakang tersebut membuat penulis bermaksud untuk melakukan penelitian berjudul "Gambaran Faktor Predisposing, Reinforcing, dan Enabling KB Vasektomi Di Kecamatan Kenjeran Kota Surabaya”.

\section{METODE}

Tujuan dari penelitian ini adalah untuk menggambarkan faktor predisposing, reinforcing, dan enabling $\mathrm{KB}$ vasektomi 
di Kecamatan Kenjeran Kota Surabaya. Penelitian ini adalah penelitian deskriptif, dengan pendekatan kualitatif. Penelitian kualitatif ini menggunakan pendekatan fenomenologi, yaitu peneliti berusaha memahami arti peristiwa serta kaitankaitannya terhadap orang-orang biasa dalam suatu situasi tertentu (Moleong, 2002).

Populasi dari penelitian ini adalah seluruh peserta KB aktif di Kecamatan Kenjeran Kota Surabaya tahun 2016. Informan penelitian dalam penelitian ini terbagi dalam 2 jenis. Penentuan informan penelitian dengan cara purposive. Kriteria inklusi dalam penelitian ini yaitu bersedia menjadi subyek dan informan penelitian dan telah menjadi akseptor KB vasektomi maksimal 2 tahun.

Informan kunci adalah peserta KB aktif di Paguyupan Kecamatan Kenjeran Kota Surabaya tahun 2016 sebanyak 6 orang yang telah memenuhi syarat kriteria inklusi, sedangkan informan tambahan dalam penelitian ini adalah 3 orang istri dari informan kunci. Dalam hal ini informan tambahan hanya berjumlah 3 orang dikarenakan 3 orang informan tambahan yang lainnya tidak bersedia di wawancara.

Lokasi penelitian dilaksanakan di paguyuban vasektomi Kecamatan Kenjeran Kota Surabaya. Pengambilan lokasi penelitian dengan berdasarkan alasan adanya cakupan peserta aktif KB vasektomi terbanyak berada di Kecamatan Kenjeran Kota Surabaya. Waktu penelitian yang digunakan adalah bulan Juli 2016 sampai Mei 2017.

Data pada penelitian ini berupa data primer dan data sekunder. Data primer diambil secara langsung dengan cara wawancara mendalam (Indept Interview). Alat pengumpulan data berupa pedoman wawancara, dan catatan lapangan. Interview guide digunakan peneliti pada proses wawancara. Teknik ini merupakan teknik pengumpulan data yang terlebih dahulu mempersiapkan daftar pertanyaan secara sistematis. Data sekunder berupa data pengguna vasektomi dari BKKBN.

Analisis interaktif sebagai teknik analisis data pada penelitian ini. Terdapat tiga komponen analisis, yaitu reduksi data, penyajian data, dan penarikan kesimpulan. Triangulasi sumber dijadikan sebagai teknik triangulasi, yaitu dengan cara mengecek balik atau membandingkan kembali derajat kepercayaan suatu informasi yang diperoleh atau dikatakan informan dengan apa yang dikatakan secara pribadi (Moloeng, 2002).

\section{HASIL DAN PEMBAHASAN}

\section{Karakteristik Informan}

Setelah dilakukan pengumpulan data hasil indepth interview, didapatkan karakteristik responden berdasarkan usia, pendidikan, dan pekerjaan. Hasil distribusi usia, pendidikan, dan pekerjaan responden dapat dilihat pada tabel 3 .

Tabel 3 menunjukkan bahwa informan kunci berada pasa kelompok umur 4561 tahun. Menurut WHO usia 45-59 tahun merupakan kategori usia lansia pertengahan (middle age), sedangkan usia 60-70 merupakan kategori usia lansia lanjut (elderly age). Usia dari informan tambahan berada pada usia dewasa. Keterlibitan informan tambahan bertujuan untuk trianggulasi data penelitian, yaitu mengklarifikasi jawaban informan kunci.

Peserta KB vasektomi adalah pria dengan kategori lanjut usia sehingga dapat diketahui usia mempunyai pengaruh terhadap kepesertaan pria dalam mengikuti program KB vasektomi. Sesuai dengan hasil penelitian dari Kurnia (2008), bahwa pemilihan metode KB dapat dipengaruhi oleh usia. Semakin bertambah usia maka semakin bertambah kedewasan berpikir dan berindakan sehingga akan lebih mudah untuk mendapatkan informasi baru. Menurut ekarini (2008), berdasarkan segi usia pemakai kontrasepsi khususnya vasektomi, memiliki kecenderungan lebih tua dibanding yang KB lain. Indikasi ini menunjukan bahwa kematangan pria juga dapat menjadi pengaruh untuk saling mengerti dalam kehidupan berkeluarga. Hal tersebut sesuai dengan hasil penelitian Yuniarti, dkk (2015) bahwa umur responden saat melakukan vasektomi yaitu $\geq 35$ tahun.

Jenis pekerjaan dapat diketahui pekerjaan yang dimiliki oleh informan kunci merupakan pekerjaan yang termasuk dalam kelompok pekerja informal. Selain itu, juga diketahui bahwa semua informan kunci memiliki tingkat pekerjaan rendah, sehingga akan berkaitan dengan penghasilan yang diterima oleh informan kunci. 
Tabel 3. Karakteristik Informan

\begin{tabular}{|c|c|c|c|c|}
\hline Inisial & Usia & $\begin{array}{c}\text { Pendidikan } \\
\text { Terakhir }\end{array}$ & Pekerjaan Spesifik & Keterangan \\
\hline $\mathrm{HE}$ & 45 & SMA & Sopir & Informan Kunci 1 \\
\hline AK & 30 & SD & Swasta & Informan Kunci 2 \\
\hline $\mathrm{HA}$ & 55 & SD & Wiraswasta & Informan Kunci 3 \\
\hline SU & 61 & SD & Rombeng & Informan Kunci 4 \\
\hline$M R$ & 48 & SD & Tukang Becak & Informan Kunci 5 \\
\hline $\mathrm{AE}$ & 47 & SMEAN & Wiraswasta & Informan Kunci 6 \\
\hline KA & 44 & SMA & Pijat Tradisional & Informan Tambahan 7 \\
\hline SZ & 54 & SD & Jualan & Informan Tambahan 8 \\
\hline UM & 56 & SD & Buruh & Informan Tambahan 9 \\
\hline
\end{tabular}

Penghasilan yang rendah menyebabkan informan untuk tidak ingin menambah anak lagi dikarenakan dengan jumlah anak yang dimiliki sekarang menyebabkan pengeluaran yang besar. Jumlah anak yang dimiliki oleh informan kunci adalah paling sedikit 3 orang dan paling banyak adalah 6 orang anak. Sebanyak 3 dari 6 orang informan kunci memiliki anak dengan jumlah 4 orang.

\section{Faktor Predisposisi (Predisposing Factor)}

\section{Pengetahuan (Knowledge) Terhadap KB Vasektomi}

Terdapat 5 dari 6 orang informan mengetahui pengertian, cara kerja, dan bagaimana cara mengikuti program KB vasektomi. HE menjelaskan bahwa cara kerja dari KB vasektomi adalah dengan cara memotong saluran sperma. Berikut cuplikan wawancara :

"Kontrasepsi itu adalah alat penunda kehamilan. Supaya tidak punya anak dulu, Ya itu dari saya ya, dipotong saluran sperma saya" (HN, 45 tahun)

Pengetahuan sebelum melakukan tindakan itu merupakan hal yang penting. Mayoritas informan sudah mengetahui semua informasi mengenai $\mathrm{KB}$ vasektomi. Hal ini yang menyebabkan pria atau suami setuju untuk mengikuti program KB vasektomi. Hasil penelitian oleh Wiyatmi (2014), diketahui bahwa pengetahuan yang baik pada masyarakat tentang vasektomi menjadi faktor utama penyebab suami memilih vasektomi sebagai kontrasepsi pilihan.
Hasil penelitian dari Wiyatmi (2014) yang menyimpulkan bahwa rata-rata pria PUS memiliki pengetahuan yang kurang atau rendah tentang vasektomi, mereka masih berpendapat bahwa biaya vasektomi mahal serta masih beranggapan bahwa vasektomi dapat mengganggu hubungan seksual menjadi bukti masih rendahnya pengetahuan akan KB vasektomi. Hasil ini menjelaskan bahwa pengetahuan merupakan faktor penentu utama yang menyebabkan seseorang memutuskan untuk memilih KB vasektomi. Adanya pengetahuan yang baik dapat mempengaruhi masyarakat memilih KB vasektomi sebagai alat kontrasepsi.

\section{Sikap (Attitude) Terhadap Pemakaian KB Vasektomi}

Hasil dari waawancara mendalam dengan melihat reaksi dari jawaban informan didapatkan kesimpulan bahwa semua informan kunci menmpunyai sikap baik dengan setuju mengikuti progrma KB vasektomi. Hasil ini sesuai dengan teori Green (1991) yang menyatakan bahwa sikap menjasi faktor predisposisi yang menentukan perilaku seseorang. Berikut cuplikan wawancara bersama informan AK:

"Saya setuju saja" (AK, 30 tahun)

Sikap merupakan gambaran kepribadian yang terlihat dalam gerakan fisik dan tanggapan pikiran akan suatu obyek atau suatu keadaan tertentu. Azwar (2004) menjelaskan bahwa sikap dari seseorang terhadap suatu obyek merupakan luapan perasaan atau emosi, faktor kedua adalah suatu respons yang akan menjadi 
kecenderungan untuk bereaksi. Alternatif sikap yaitu senang atau tidak senang, menurut dan melaksanakan atau menjauhi dan menghindari sesuatu. Sikap adalah suatu predisposisi evaluatif yang akan menentukan bagaimana individu bertindak. Semakin baik sikap terhadap program KB maka semakin banyak kemungkinan untuk ikut aktif dalam pelaksanaan program KB. Menurut informan HA diketahui bahwa dengan mengikuti program KB vasektomi dapat menekan biaya pengeluaran yang diperlakan untuk suntik KB pada isteri.

"Ya langsung ikut soalnya untuk lebih menghemat uang karena kalo suntikan 3 bulan sekali agak mahal jadi langsung ikut ini aja mbak" (HA, 55 tahun)

Menurut Peraturan Menteri Kesehatan nomor 52 tahun 2016 menjelaskan bahwa pelayanan suntik KB sebesar Rp. 15.000 setiap kali suntik. Dengan adanya keikutsertaan suami pada program KB vasektomi akan mampu mengurangi biaya rutin yang harus dikeluarkan keluarga untuk program KB karena pada vasektomi hanya dilakukan satu kali. Berdasarkan penelitian Wahyuni (2013), menyatakan bahwa terdapat hubungan yang bermakna terhadap sikap akseptor KB pria dengan partisipasi vasektomi. Pemahaman yang benar akan pengetahuan tentang penggunaan alat kontrasepsi pria dan sikap terhadap KB vasektomi yang lebih positif akan mendukung keterlibatan pria untuk mengikuti dan menggunakan KB vasektomi, selanjutnya pria yang memiliki sikap kurang baik terhadap vasektomi akan mengurangi keinginan dan partisipasinya untuk mengikuti program KB vasektomi.

\section{Keyakinan (Belief) Terhadap Pemakaian $K B$ Vasektomi}

Semua informan meyakini bahwa penggunaan KB vasektomi tidak memiliki efek samping serta mampu memberikan dampak positif. Berikut cuplikan wawancara bersama informan $\mathrm{AE}$ :

"Sampai sekarang nggak ada (dampak) mbak, katakanlah operasi kecil lah itu tanpa alat pisau cuman penjepit itutok di tarik digunting diikat jadi atas bawah diikat. Cuman saluran benih tok yang diikat dan saluran airnya enggak" ( $A E, 47$ tahun)

Informan UM sebagai informan tambahan juga menyatakan tidak terdapat efek samping dari penggunaan KB vasektomi pada suaminya. Informan juga mengetahui informasi mengenai alat kontrasepsi sehingga tidak takut terjadinya dampak buruk terhadap suaminya. Informan juga mengatakan bahwa KB yang dilakukan suaminya adalah aman. Cuplikan wawancara bersama informan UM sebagai berikut :

"Nggak ada efek samping nya kan ya mbak, saya tau dan nggak takut. Pokoknya saya tau itu aman gitu" (UM, 56 tahun)

Semua informan kunci juga meyakini bahwa KB vasektomi tidak sama dengan kebiri, sehingga informan merasa yakin dan percaya pada tindakannya untuk berpartisipasi dalam KB vasektomi. Berikut cuplikan wawancara bersama informan SU:

"Kalau MOP itu biar nggak punya keturunan lagi. Kalau kebiri itu alat kelaminnya di potong" (SU, 61 tahun)

Adanya keyakinan yang baik dari semua informan kunci juga menyebabkan tidak adanya informan yang menyesal setelah mengikuti program ini. Hasil penelitian Santiso, dkk (2011) juga menyatakan bahwa 97\% merasa puas terhadap tindakan vasektomi dan tidak menyesal.

Stigma dari KB vasektomi adalah berkaitan dengan faktor seksual, vasektomi dianggap dapat menyebabkan pria menjadi kehilangan kejantanannya. Padahal hal tersebut tidak benar, karena berdasarkan proses tindakan, vasektomi hanya memutus kontinuitas vas deferens sehingga terjadi hambatan penyaluran spermatozoa melalui saluran tersebut. Sumbatan pada vas deferens tidak mempengaruhi jaringan intersitiel pada testis, sehingga sel-sel leydig tetap menghasilkan hormon testosteron seperti biasa dan produksi hormon testosteron tidak terganggu, maka libido juga tidak berubah (Taher, dkk, 2003). 
Vasektomi tidak menjadi penyebab laki-laki menjadi impoten karena saraf-saraf dan pembuluh darah yang berperan dalam proses terjadinya reaksi berada dibatang penis, sedangkan tidakan KB vasektomi hanya dilakukan di sekitar buah zakar atau testis sehingga vasektomi tidak akan mengganggu kemampuan penis untuk ereksi (BKKBN, 2012). Selain itu, vasektomi tidak akan menyebabkan fungsi dari kelenjarkelenjar asesoris berubah sehingga produksi semen tetap berlangsung dan pria yang divasektomi tetap berejakulasi (Taher. dkk, 2003).

Tindakan vasektomi tidak sama dengan tindakan pengebirian. Tindakan pengkebirian merupakan tindakan membuang buah pelir untuk membuang kejantanan, sedangkan vasektomi hanya memotong atau mengikat saluran sperma kiri dan kanan, tujuannya adalah cairan mani yang dikeluarkan pada saat ejakulasi tidak lagi mengandung sperma. Operasi vasektomi memakan waktu sekitar 10-15 menit dengan menggunakan bius lokal, sehingga tidak memerlukan anestesi (busi) umum (BKKBN,2008).

\section{Jumlah anak Peserta KB Vasektomi}

Menurut hasil wawancara dapat diketahui bahwa jumlah anak dari informan kunci adalah 3-6 orang. Kondisi kesehatan suami atau istri, kesiapan mental serta kemampuan ekonomi menjadi pertimbangan dalam menentukan jumlah anak dan jarak kelahiran anak (BKKBN,2008).

Terdapat dukungan juga dari isteri informan kunci agar suaminya dapat mengikuti program KB vasektomi. Menurut informasi SZ faktor yang menyebabkan dirinya mendukung suami untuk melakukan KB adalah karena kondisi telah memiliki jumlah anak yang banyak.

Berikut cuplikan wawancara bersama informan SZ:

\section{"Saya mendukung suami karena anak saya sudah 5 dan sudah besar semua. Lalu suami itu juga kadang nggak ngerti merawat luka pasca operasi, jadi saya repot sendiri" (SZ, 54 tahun)}

Data penelitian ini juga menunjukkan bahwa jumlah anak yang dimiliki oleh sebagian besar responden sebelum menggunakan $\mathrm{KB}$ vasektomi adalah >3 orang. Hal tersebut berlawanan dengan program KB yang sering diutarakan yaitu dengan 2 anak lebih baik lakilaki perempuan sama saja maka sudah seharusnya suami mengambil peran dalam ber-KB.

Kehamilan risiko tinggi juga dapat ditimbulkan pada kehamilan setelah 4 kelahiran. Jika ditinjau dari sudut kematian maternal paritas 2-3 adalah paritas paling aman kemudian paritas satu dan paritas lebih dari tiga mempunyai angka kematian terhadap ibu. Paritas tinggi dapat di hentikan atau dicegah dengan kontrasepsi mantap. Kontrasepsi mantap yang dapat dipilih oleh suami adalah vasektomi yang aman, efektif dan mantap dalam menanggulangi jumlah anak yang banyak. Keputusan untuk memiliki sejumlah anak merupakan suatu pilihan bersama antara suami dan istri.

Pemerintah telah menyampaikan informasi mengenai program KB yakni membatasi pasangan untuk memiliki hanya 2 anak saja. Kenyataannya, masyarakat yang mengikuti KB sudah memiliki anak lebih dari 2, bahkan pada penelitian ini rata-rata memiliki 4 orang anak. Faktor lain yang menyebabkan pria ikut berpartisipasi pada program KB vasektomi adalah karena jumlah anak. Peningkatan jumlah anak maka semakin meningkat pula beban yang ditanggung oleh orang tua. Hal ini berkaitan dengan pengeluaran yang meningkat karena bertambahnya kebutuhan dalam keluarga. Kondisi ini dialami oleh informan $\mathrm{HE}$ yang menjelaskan keikutsertaannya dalam KB vasektomi karena sudah memiliki 6 orang anak padahal penghasilan yang didapatkan oleh informan HE hasih tetap seperti biasanya.

\section{"Anak saya sudah 6, penghasilan saya gini-gini saja, jadi saya memutuskan untuk KB juga saja" (HE, 45 tahun)}

Situasi inilah yang memberikan dorongan kepada informan HE untuk melaksanakan program tersebut agar merencanakan tidak menambah jumlah anak lagi dan membuat kemungkinan tidak mengeluarkan biaya yang bertambah. Hal ini juga diakui berhubungan dengan penghasilan yang didapatkan informan 
karena dirasa tidak mencukupi jika akan memiliki tambahan anak.

\section{Kesadaran Suami Untuk Menggunakan $K B$}

Hasil wawancara dengan informan diketahui bahwa kesadaran suami untuk menggunakan KB juga menjadi faktor pendorong bagi pria untuk berpartisipasi dalam program KB. Informasi yang disampaikan oleh informan AK menyebutkan bahwa program KB bukan hanya menjadi tanggungjawab isteri tetapi juga tanggungjawab suami.

"Ya sama juga perempuan sama juga laki-laki, sama-sama tanggung jawablah" (AK, 30 tahun)

Pelaksanaan dan pengembangan program KB pria ditujukan untuk mewujudkan keadilan dan kesetaraan gender. Apabila seorang suami memahami bahwa KB merupakan program yang menjadi tanggungjawab suami dan isteri maka akan meningkatkan partisipasi masyarakat dalam mengikuti KB vasektomi. Selama ini penggunaan KB pada wanita mengalami berbagai kendala seperti mengalami perdarahan yang banyak pada saat menstruasi, berat badan meningkat, jerawat, dan flek.

Soleha (2016) menyebutkan bahwa dampak dari penggunaan KB pada wanita adalah timbulnya rasa pusing dan mual, menyebabkan siklus haid tidak teratur berkepanjangan atau bahkan tidak haid sama sekali serta menurunnya gairah seksual pada wanita. Sementara informan HA menjelaskan bahwa penggunaan alat kontrasepsi suntik pada istrinya dikhawatirkan akan menyebabkan kegemukan.

\section{"Ibunya waktu itu pernah ikut tapi sekarang tidak mau lagi karena takut mengalami kenaikan berat badan jadi gantian bapaknya yang ikut Kb ibunya tidak"( $H A$, 55 tahun)}

Hal ini diperkuat oleh penelitian dari Ekawati (2010) yang menyebutkan bahwa efek jangka panjang dari KB suntik dapat memicu terjadinya kanker, peningkatan berat badan, kekeringan pada vagina, jerawat serta gangguan emosi akibat dari penggunaan hormonal yang lama sehingga mengacaukan keseimbangan hormone estrogen dan progesteron.

Hal ini juga diakui oleh informan SZ yang menjelaskan bahwa keinginan suami untuk menggunakan KB vasektomi karena tidak menginginkan isterinya mengikuti KB terus-menerus. Selain itu, suami sudah mengetahui dampak kesehatan yang terjadi pada isteri karena mengikuti program KB. Melalui penelitian ini dapat dijelaskan bahwa terdapat faktor predisposisi pada pria yang mengikuti program KB vasektomi yakni keinginan untuk menggantikan isteri dalam mengikuti program KB.

\section{Faktor Pemungkin (Enabling Factor)}

Faktor pemungkin mencakup faktor berbagai keterampilan dan sumber daya yang merupakan poin penting yang diperlukan dalam suatu perubahan perilaku kesehatan. Fasilitas pelayanan kesehatan, personalia klinik keterjangkauan sumber daya serta biaya, jarak ketersediaan transportasi, waktu dan sebagainya menjadi sumberdaya yang perlu diperhatikan. Dari hasil penelitian ini dapat diketahui 1 orang informan mengatakan bahwa biaya untuk berpartisipasi pada program KB vasektomi terjangkau.

\section{"Kalau menurut saya sih masih terjangkau lah dengan penghasilan saya yang cuman segitu dan pekerjaan saya yang jadi sopir ini" (HN, 45 tahun)}

Menurut Permenkes 53 tahun 2016 menjelaskan bahwa biaya pelayanan keluarga berencana dengan metode MOP atau vasektomi adalah sebesar Rp. 350.000 dan dilakukan hanya sekali sehingga biaya $K B$ vasektomi lebih murah.

Lima orang informan mengakui bahwa dalam melaksanakan KB vasektomi tidak mengeluarkan biaya. Selain itu, juga salah satu pria yang melakukan KB vasektomi mendapatkan uang, obat-obatan dan sembako dari pihak safari KB DP5A (Dinas Pengendalian Penduduk, Pemberdayaan Perempuan, dan Perlindungan Anak) Kota Surabaya. Pada saat pihak sponsor mengadakan suatu acara di kecamatan, salah satu yang diberikan insentif berupa uang dan sembako adalah pria yang 
menggunakan KB vasektomi dan wanita yang dalam satu tahun melakukan pap smear. Dalam hal ini pria yang sedang mengikuti acara tersebut tidak mengetahui bahwa akan diberikan uang dan juga sembako. Berikut salah satu cuplikan wawancara bersama informan $\mathrm{HA}$ :

"Enggak mbak malah dikasih uang 100 berapa gitu mbak sama sembako di tahun 2015" (HA, 55 tahun).

Faktor pemungkin pria untuk berKB adalah kemudahan akses, informan menyatakan bahwa pelayanan KB vasekomi sangat mudah dan pelayanan yang diberikan bagus. Informan AK mengatakan bahwa pelayanan KB vasektomi sangat baik hal itu juga sejalan dengan obat-obat yang diberikan yaitu sangat lengkap dan memuaskan.

"Baik, dokternya baik, obatobatnya juga nggak ada masalah" (AK, 30 tahun)

Menurut Green (1991) akses untuk mendapatkan pelayanan kesehatan menjadi salah satu faktor pemungkin (enabling) yang memengaruhi seseorang untuk bertindak atau tidak bertindak. Wiyatmi (2014) menyimpulkan terdapat hubungan yang signifikan dari akses pelayanan dengan sikap pria PUS terhadap metode vasektomi di Desa Winong Boyolali. Wiyatmi (2014) mengansumsikan bahwa akses terhadap pelayanan KB pria di Desa Winong mudah diakses. Dengan adanya kemudahan akses serta ketersediaan pelayanan KB berdampak positif terhadap penggunaan suatu alat kontrasepsi. Dengan adanya kemudahan akses dan baiknya layanan memungkinkan untuk berpartisipasi.

\section{Faktor Penguat (Reinforcing Factor)}

Hasil penelitian ini menunjukkan bahwa yang menjadi faktor penguat bagi mereka yang mengikuti program KB vasektomi adalah dengan adanya dukungan isteri. Menurut informan MR isteri memberikan dukungan mulai dari awal sampai dilaksanakan KB vasektomi. Hal tersebut dilakukan melalui diskusi bersama dan mendukung untuk mengantarkan ke dokter. Dengan adanya dukungan dari isteri menyebabkan suami mau berpartisipasi dalam program KB vasektomi.

"Yang ngajak malah isteri mba, diskusi dulu mba" (MR, 48 tahun)

Dukungan akan menjadi dampak yang positif baik itu secara fisik, mental serta kehidupan sosial seseorang. Dukungan isteri terhadap tindakan vasektomi yang akan dilakukan oleh suami akan membuat perasaan suami menjaadi lebih tenang.

Penelitian lain menunjukkan penyebab rendahnya partisipasi pria untuk menjadi peserta KB disebabkan oleh faktor keluarga, antara lain isteri tidak mendukung (BKKBN, 2006). Hasil penelitian lain diketahui bahwa, terdapat hubungan yang signifikan antara sikap isteri terhadap partisipasi pria dalam KB (Simanullang, 2011). Hasil penelitian Wira (2014) diketahui bahwa ada pengaruh bermakna antara dukungan istri dengan penggunaan vasektomi di Kota Bandar Lampung Provinsi Lampung dengan derajat keeratan nilai $\mathrm{OR}=20,364$, yang berarti bahwa responden yang tidak mendapat dukungan istri mempunyai peluang untuk tidak vasektomi sebanyak dua puluh kali kali lebih tinggi dibandingkan responden dengan yang mendapat dukungan istri.

Permasalahan KB tidak hanya masalah demografi ataupun klinis akantetapi juga masalah sosial budaya serta agama. Dalam Undang-undang nomor 10 tahun 1992, penyelenggaraan pengaturan kelahiran dilakukan dengan cara yang dapat dipertanggungjawabkan baik itu dari segi etik, kesehatan maupun agama. Masyarakat serta tokoh masyarakat ataupun tokoh agama perlu mendukung program KB.

Pada penelitian ini diketahui bahwa semua informan beragama Islam dan menyatakan bahwa pelaksanaan KB yang dilakukan tidak bertentagan dengan syariat agama yang dianut. Selain itu, informan HE dan AK memberikan penjelasan bahwa tidak ada aturan yang menyatakan bahwa pelaksanaan KB haram.

"Kalau dalam agama saya, hal tersebut sah-sah saja. Tidak ada larangan atau mengatakan itu haram" (HE, 45 tahun)

Informan AE menyatakan bahwa sudah pernah berdiskusi bersama tokoh 
122 Jurnal Promkes: The Indonesian J ournal of Health Promotion and Health Education Vol. 7 No. 1 (2019) 113-123. doi: 10.20473/j jk. V7.I1.2019.113-123

masyarakat dan tokoh agama mengenai program KB. Namun, informan menyatakan bahwa tokoh agama dan tokoh masyarakat membolehkan pelaksanaan program ini. Hal ini menjelaskan bahwa masyarakat menganggap bahwa pelaksanaan KB adalah halal sehingga menjadi faktor penguat untuk melaksanakannya.

"Jadi bapaknya yg ikut tapi pertamanya bapaknya tidak mau, tapi setelah tanya dokter sama ustadz boleh -boleh saja" (AE, 47 tahun)

Para ulama telah membolehkan untuk melakukan KB dengan kesepakatan bahwa KB adalah usaha untuk mengatur atau menjarangkan suatu kelahiran ataupun usaha untuk mencegah kehamilan sementara atas kesepakatan suami isteri. Hal ini sesuai dengan tujuan dari program $\mathrm{KB}$, yaitu untuk menunjang program pembangunan kependudukan, serta menjaga kesehatan ibu dan anak.

Faktor panutan menjadi faktor lain sebagai alasan informan dalam memilih vasektomi. Unsur panutan menjadi suatu unsur pengalaman yang dapat dilihat oleh orang lain secara nyata bahwa KB yang digunakan tidak berbahaya. Panutan menjadi suatu pengaruh besar dalam pembentukan pribadi seseorang sebelum seseorang memutuskan apakah suatu perilaku itu berbahaya atau tidak untuk dirinya. Dalam penelitian ini yang menjadi panutan untuk mengikuti program KB vasektomi adalah masyarakat yang sudah tergabung dalam paguyuban KB pria di Kecamatan Kenjeran. Tokoh-tokoh dalam paguyuban ini berperan sebagai motivator yakni mengajak dan mendorong informan untuk mengikuti program KB vasektomi serta juga berperan deseminator yakni memberikan informasi dan menyampaikan makna dari program ini.

Tersedianya informasi yang benar, jelas dan lengkap dapat menjadi bahan pertimbangan, sehingga informasi metode Keluarga Berencana tidak boleh disembunyikan sehingga calon peserta bisa memilih jenis kontrasepsi yang sesuai dan diinginkan. Penyampaian dalam edukasi, konseling dan keterampilan penyedia layanan kontrasepsi vasektomi yang jelas dan lengkap akan meningkatkan penerimaan dan pemakaian kontrasepsi vasektomi (Wulansari, 2006).

\section{SIMPULAN}

Sebagian besar informan memiliki pengetahuan dan sikap yang baik terhadap KB vasektomi dengan menyakini penggunaan KB vasektomi tidak memiliki efek samping dan tidak sama dengan kebiri. Jumlah anak yang banyak dan kesadaran suami untuk mengikuti KB, juga mempengaruhi keikutsertaan dalam program KB vasektomi. Hal ini disebabkan adanya gangguan kesehatan yang dialami istri seperti perdarahan yang banyak pada saat menstruasi, berat badan meningkat, jerawat, flek.

Faktor pemungkin (enabling factor) menjelaskan sebagian kecil informan menyatakan biaya untuk berpartisipasi pada KB vasektomi terjangkau. Sebagian besar menyatakan gratis serta didukung akses pelayanan pada program KB vasektomi sangat baik. Faktor penguat (reinforcing factor) diketahui bahwa sebagian besar informan mendapatkan dukungan dari istri. Semua responden percaya bahwa KB vasektomi adalah halal meskipun hanya sebagian kecil yang mendapatkan dukungan dari tokoh agama. Dukungan dari paguyuban berupa motivator dan deseminator juga menyebabkan pria mengikuti KB vasektomi.

\section{DAFTAR PUSTAKA}

BKKBN. 2006. Keluarga Berencana Kesehatan Reproduksi, Gender dan Pembangunan Kependudukan, Edisi Revisi. Jakarta: BKKBN.

BKKBN, 2006. Panduan Pelayanan Vasektomi Tanpa Pisau. Jakarta: PT. Bina Pustaka.

BKKBN. 2008. Panduan pelaksanaan KIP/ konseling kontrasepsi pria. Jakarta: BKKBN.

BKKBN. 2012. Gema Pria Pusat Informasi KB Pria. [online] (http://gemapria.bkkbn. go.id/consult-detail.php?conid=1377). Di-akses pada tanggal 7 Februari 2018.

BKKBN, 2012. Pedoman Pelayanan Keluarga Berencana Pasca Persalinan dan Fasilitas Kesehatan. Jakarta: PT. Bina Pustaka. 
BKKBN, 2015. Rencana Strategis Badan Kependudukan dan Keluarga Berencana Nasional tahun 2015-2019. Jakarta: PT. Bina Pustaka.

BKKBN, 2016. Kebijakan Program Kependudukan, Keluarga Berencana, dan Pembangunan Keluarga dalam Mendukung Keluarga Sehat. Jakarta: PT. Bina Pustaka.

BKKBN, 2016. Rapat Pengendalian Program Bulan November 2015 sampai Bulan Januari 2016. Surabaya.

Dalem, 2012. Faktor yang mempengaruhi bias gender penggunaan kontrasepsi pada pasangan usia subur di desa Dawan Kaler Kecamatan Dawan Klungkung. Piramida vol VIII No.2 : 93-102

Ekarini S.M.B. 2008. “Analisis Faktor-Faktor yang Berpengaruh terhadap Partisipasi Pria dalam Keluarga Berencana di Kecamatan Selo Kabupaten Boyolali”. Skripsi. Universitas Diponegoro: Semarang.

Ekawati, D., 2010. “Pengaruh KB Suntik DMPA Terhadap Peningkatan Berat Badan di BPS Siti Syamsiah Wonokarto Wonogiri". Karya Tulis Ilmiah. Univerisitas Sebelas Maret: Surakarta.

Green, L.W. 1991. Health Promotion Planning, Educational and Environmental Approach. The John hopkins University. Mayfieldy Publishing. USA.

Jersild AT. 1965. The psychology of adolesence. New York: The MacMillan Company.

Kurnia, R.A. 2008. Pengetahuan Kontrasepsi vasektomi pada suami ditinjau dari umur, pendidikan, dan pekerjaan. Fakultas Kesehatan Masyarakat Universitas Airlangga. Surabaya.

Moleong, Lexy. (2002). Metodologi Penelitian Kualitatif. Bandung: PT. Remaja Rosdakarya.

Noor, N.N., 2008. Epidemiologi. Jakarta: Rineka Cipta.

Notoatmodjo, 2007. Promosi Kesehatan \& Ilmu Perilaku. Jakarta: PT Rineka Cipta.

Santiso, R., Pineda, MA., Marroquin, M., dan Ber-trand, J.T. 2011. Vasectomy in Guatemala: A follow-up study of five hundred accep-tors. Biodem \& Soc Bio: 28(3-4): 253-64.
Simanullang R. 2011. "Pengaruh faktor predisposisi, pemungkin dan penguat peserta kontrasepsi pria terhadap penggunaan vasektomi di kecamatan Labuhan Deli Kabupaten Deli Serdang”. Skripsi. Universitas Sumatera Utara. Medan.

Soleha, S., 2016. Studi Tentang Dampak Program Keluarga Berencana di Desa Bangun Mulya Kabupaten Penajam Paser Utara. Jurnal Ilmu Pemerintahan, 4 (1), 2016 : 39-52. Universitas Mulawarman. Samarinda

Sugiyono. 2013. Metode Penelitian Kuantitatif Kualitatif dan $R$ \& $D$. Bandung: Alfabeta.

Survei Dasar Kesehatan Indonesia. 2007. http://www.bkkbn.go.id/Webs/upload/ data/ SDKIMIX.pdf [ Diakses pada 8 Februari 2018]

Taher, A., Rasyid, N., Asri., dan Mu'ammar. 2003. Buku acuan vasektomi tanpa pisau. Jakarta: Perkumpulan Kontrasepsi Mantap Indonesia (PKMI).

Wahyuni, 2013. Hubungan Pengetahuan Dan Sikap Akseptor KB Pria Tentang Vasektomi Serta Dukungan Keluarga Dengan Partisipasi Pria Dalam Vasektomi di Kecamatan Tejakula Kabupaten Bulelang. Jurnal Magister Kedokteran Keluarga Vol 1, No1, 2013 : 80-91. Universitas Negeri Solo. Surakarta.

Wira, V. U., 2014 . Faktor-faktor yang Mempengaruhi Penggunaan Vasektomi di Kota Bandar Lampung. Jurnal Kesehatan Holistik Vol 8, No 3, Juli 2014 : 115-119. Universitas Malahayati Bandar Lampung. Lampung.

Wiyatmi. 2014. Faktor - Faktor Yang Berhubungan Dengan Sikap Pria Pasangan Usia Subur (Pus) Tentang Metode Kontrasepsi Vasektomi Di Desa Winong Kecamatan Boyolali Kabupaten Boyolali. Skripsi. Universitas Muhammadiyah Surakarta. Surakarta

Wulansari, H. 2006. Ragam Metode Kontrasepsi. Jakarta: EGC.

Yuniarti., Rusmilawaty dan Zakiah. 2016. Faktor yang Berhubungan Dengan Keikutsertaan Suami Pada Program KB Vasektomi di Wilayah Kecamatan Banjarmasin Timur. Jurnal Kesehatan, Volume VI, Nomor 2, Oktober 2015, hlm 167-171. Poltekkes Kemenkes Banjarmasin. Banjarmasin. 